DANIEL M. KNIGHT

University of St. Andrews

[rh]Cosmopolitan futures

Volume 44 Issue 2 May 2017

[ti]Anxiety and cosmopolitan futures:

\title{
Brexit and Scotland
}

[ab]Two themes, temporality and cosmopolitanism, repeatedly arose during conversations in Scotland with people who favored remaining in the European Union. The 2016 referendum's result in favor leaving the EU has affected how they think about their temporal trajectories and what they might do to maintain their cosmopolitan ideals, which are now deeply shaken. Both Scots and non-UK EU nationals living in Scotland must confront the uncertainty of what impact Brexit will have on the freedom of trade and movement. This uncertainty provokes a new set of anxieties, expectations, and speculations as they contemplate how these changes might affect them personally. They feel especially uncomfortable that cosmopolitanism has become entwined with the nationalist projects of both Edinburgh and London. [temporality, cosmopolitanism, nationalism, Brexit, Scotland, United Kingdom, European Union]

[dc]Dennis felt his eyes welling up with tears as he looked over the small print of a UK Permanent Residence application, which he was completing for 
his partner, Giovanna, an Italian national. ${ }^{1}$ A 35 -year-old working-class Englishman, Dennis was already tired from peering through the darkness of the small hours at the television to watch the fallout of the historic UK referendum on European Union membership. He felt empty, persecuted, stripped of the very core of what he had believed to mean "England"cosmopolitanism, multiculturalism, open-mindedness, social liberties. For, although he and Giovanna had lived in Scotland (which voted overwhelmingly to remain in the European Union) for the past seven years, he lamented that the Brexit result was very much an "English 'victory."' The brightly colored results map confirmed that his compatriots had disowned him. "Not much less than an act of treason," he proclaimed. He told me that bitter questions kept flashing across his mind: "Why should we have to do this?" "Who is making us fill in this form?" "What right have they to force me into this decision?"

As we sat at his dining-room table, 85 sheets of paper spread out before us, tears started trickling down his cheek, inky ripples dispersing across page 15 of the UK Visas and Immigration document. With half their family in Italy and having recently secured employment in a sector heavily reliant on EU trade deals, Dennis and Giovanna saw their immediate future as quite uncertain. This was exactly what Dennis had told his mother would happen, he kept muttering, if the voting public were persuaded by the leading proponents of Brexit-former mayor of London Boris Johnson and 
Nigel Farage, the leader of the right-wing UK Independence Party. Their call to arms used a rhetoric of intolerance toward alterity, which they linked to the very real pains incurred during eight years of fiscal austerity.

Dennis, who is a manager of a small electronics outlet store and the first person in his family to receive a university education, described feeling sick to his stomach about his English identity. Brexit felt like a personal and professional attack on him, his family, and his beliefs in British national identity. He was so disappointed with his compatriots, particularly on behalf of the youth who generally voted to remain part of the European Union, although he tried to understand their reasons for wanting to leavesomething he ascribed to excruciating austerity, job losses, and the incessant plundering of national resources by big business and the political class. He was proud of his working-class background and said he was frustrated at how Brexit was being portrayed as a new era of class warfare. Sweeping class categorizations, he suggested, overlook complex individual circumstances, such as when "a working-class man marries a foreigner."

I felt Dennis's pain. From the upper-working-class southwest of England, my family, like Dennis's and so many others, was also split between the opposing camps of Leave and Remain. My arguments for the merits of cosmopolitanism, European freedoms, and the potential impact on our own family (my partner is also a non-British EU citizen) were often rebutted with anecdotes of struggles to find secure employment, migrants' 
alleged criminal activities, and the need to control national borders. Even then I felt that this referendum would be hijacked, like Greece's referendum on a financial bailout plan in July 2015 and the Italian vote on constitutional reform in December 2016; the question on the ballot served short-term political gains by manipulating voters, playing on the insecurities of a public tired with the seeming inability and incompetence of European politicians to deal with the dual crises of economy and immigration.

Further, as Karen Sykes (2016) notes, many people over the following days said they had not thought the election result would lead to Brexit. They were indeed voting against austerity politics, immigration, and big business, but many, it would seem, had not planned on losing the privileges of EU membership. Similar voices could be heard in both Italy and Greece after referendums there-everyone appeared to have a different interpretation of what the question on the ballot actually meant (or implied) vis-à-vis future membership in the European project. As demonstrated by Insa Koch (2017), the premises on which people voted were a far cry from the supposedly simple binary of a referendum question.

Varied and contradictory interpretations of the referendum result were not difficult to find at my university. The department in which I work at the University of St. Andrews hosts both a Centre for Cosmopolitan Studies and a Centre for Minorities Studies. St. Andrews is a university that once had John Stuart Mill, the champion of liberalism, freedom, and individuality, as 
its lord rector, the representative of students who spoke truth to institutional power. A university, incidentally, to which Boris Johnson sent his daughter to study, choosing to attend her graduation ceremony on the day of the referendum. A small-town home to over 150 nationalities enshrined in its cosmopolitan bubble, even by the pro-Remain standards of Scotland, St. Andrews was hit particularly hard by the Leave vote (on educational capital, see Gusterson 2017). Since the referendum there has ensued a power struggle among the Conservative Party government, the courts, the European Union, and the constitutive devolved administrations of the United Kingdom as to the direction of future negotiations. During this struggle people like Dennis and Giovanna have been trying to unpack the affective and practical complexities of Brexit.

In discussions with my colleagues, students, and friends in Scotland, I have noticed two key topics regularly resurfacing: temporality and cosmopolitanism. Both themes are intrinsically linked to reconstituted futures filled with new anxieties, expectations, and speculations. For many British people, and particularly in towns such as St. Andrews, everyday life has for decades been defined by cosmopolitanism-a recent past folded into a protracted present built on intimate interaction with the Other. In short, cosmopolitanism based on individual freedoms, tolerance, and social liberties has been a cornerstone of previous temporalities of Scottish European belonging (Lino e Silva and Wardle 2016; Rapport 2012b). The Brexit vote 
has thrown cosmopolitanism into suspension, leaving people like Dennis, Giovanna, and myself to question their past beliefs about the cosmopolitan project, as well as its present conditions and future trajectories.

Of course, this is not the case for swathes of the British public that welcomed the Brexit vote with euphoria. Yet, as important as it may be to understand why 52 percent of the electorate voted Leave, it is also essential to try to comprehend how those who feel they lost the referendum envision their lives in Brexit Britannia, fearing that their work and family life may be irrevocably altered. The uncertainty has affected how some in Scotland have thought about their temporal trajectories and emergent (or not) cosmopolitan futures, which have become entwined with the nationalist projects of both Edinburgh and London.

\section{[h1]Lost in Brexit: The vortex of the present and suspended}

\section{cosmopolitanism}

[ni]A once-unyielding version of Scotland's future is now past, or at least on

hold: a future in which Scotland is tied to a particular kind of European cosmopolitanism, involving closer cultural integration, freedom of work and movement, tariff-less trade, and boundless socioeconomic prosperity. From my own experience growing up in the cultural renaissance era of 1990s New Labour Britain-an era known as Cool Britannia, which was full of optimism about what the new millennium might bring-belonging to a cosmopolitan 
Europe riding high on its most recent plans for tighter integration in the form of the monetary union was the birthright of a whole generation. ${ }^{2}$ The fairy tale began to fracture with fiscal troubles in the mid-2000s, especially after the bursting of the US housing bubble led to the collapse of financial companies and a global economic downturn.

Temporal disorientation is a prominent feature in situations of crisis and chronic uncertainty. In Greece, where I have conducted research since 2003 and which serves as a source of comparison on turbulent relations with Europe, the impact of fiscal instability has been particularly harsh, with the economic turmoil and the subsequent austerity measures imposed as part of three international bailout packages (Knight 2015). After nearly three decades of prosperity, aspirations for the future were quite violently torn away from my research participants to be replaced by austerity, unemployment, fears of hunger, and social destitution.

People in Greece reported feelings of intense temporal vertigo: confusion and anxiety about where and when they belong in overarching time lines of pasts and futures. My research participants described feeling "dizzy" and "nauseous" with this confusion, of being lost, suspended, or trapped in time (Knight 2016, 35). With lowering living standards, some people said they felt as though they had been "thrown back in time" to "premodern," "pre-European" eras of poverty and suffering, while others 
discussed their experiences of the crisis as reliving multiple moments from the past assembled in the present.

Although not yet so extreme because Brexit has predominantly fueled imaginations for potential adversities yet to come, similar feelings of temporal vertigo and suspended futures are being experienced by some in postreferendum Britain. Crisis often stimulates how people think about time, whether tilted in the direction of historicizing, presentifying, or futural thought. As Charles Stewart and I have recently argued, "In moments of extreme crisis, time becomes elastic-the time waiting for a bomb to explode or a fist to land can seem like an eternity, or a blink of the eye" (Knight and Stewart 2016, 3).

For instance, discussing the referendum outcome with colleagues at St. Andrews and further afield, I started to realize that we were living firsthand what Rebecca Bryant $(2014,2016)$ has termed the "uncanny present"-the feeling of existing in an elongated, hyperconscious present that is under exaggerated interrogation. At a time of uncertainty, "we acquire a sense that what we do in this present will be decisive for both the past and the future, giving to the present the status of a threshold" (Bryant $2016,20)$. The present is brought into consciousness, creating an unusually overburdened perception of presentness: the present becomes "uncanny." The familiar is made strange. The present feels "distorted and disturbed" owing to the looming edifice of crisis leaking through its cracks. For instance, 
the morning after Donald Trump's election, a Democrat-supporting US PhD student in my department described how, after waking at 7 a.m. and fearing the worst, she had stayed in bed with her headphones in and music turned up extra loud as she tried to savor "the last few minutes of normality" before her world was turned upside down. She tried to block out or at least delay the future by elongating the now. "I didn't want to leave the comfort of the present," she remarked.

One may also think of this hyperconscious reflection on the present in terms of Ernesto de Martino's (2012) "crisis of presence," in which one can have out-of-body experiences, on the ceiling or the other side of the room, watching oneself suffering. The reality of the present-one's historicity, the historical continuity grounding the present-is momentarily lost. The uncertainty caused by the referendum has obliged some sections of the British population to critically contemplate everyday activities and rights that they had formerly taken for granted-such as the right of other European nationals to work in the United Kingdom, which now occupies Dennis's mind day and night.

Other orientations to the future are also pertinent to the postreferendum vibe in Britain: speculation, expectation, anticipation, potentiality, hope and their flip sides of resignation, apathy, exhaustion. When EU nationals and Remain supporters in Scotland discuss futures of cosmopolitanism and individual freedoms, anxieties and speculative 
hypothesizing reach previously unprecedented levels, and political speeches and television newsreels are eagerly anticipated, to be dissected in an oftenfruitless search for a glimmer of hope.

As an observation of potentiality, speculation-the forming of a conjecture without firm evidence-offers a mode of participation in the future that may be facilitated or curtailed by Brexit. Speculation goes along with a distinctive temporal disposition toward creatively contemplating some possibilities while excluding others (Weszkalnys 2015, 623). Speculation from the present as to what both the Brexit and the Trumpocene future might hold often pushes us into unknown realms on topics of warfare, financial trading, and climate change. Speculation in a Europe in the clutches of chronic political and economic turmoil is currently personal, societal, industrial, involving intense conjecture about what form a postapocalyptic future might take.

\section{[h1]Scotland: Britain's cosmopolitan heartland?}

[ni]Dennis and Giovanna see a perverse temporal contradiction between the Brexit vote and the electoral victory of Donald Trump in the United States nearly five months later. Trump's election, they suggest, signals a temporary change of direction for US citizens. But while Trump's presidency is now a certainty, Brexit will be a permanent change but, with all the uncertainty, may never happen at all. The level of precariousness surrounding a deal that 
has permanent (or at least long-term) consequences, Dennis argues, makes it all the more important for his partner to secure residency rights and eventually apply for British citizenship. They cannot live with the physical and psychological effects of chronic uncertainty stoked by media hyperbole and scaremongering.

Since the Brexit vote, Scottish first minister Nicola Sturgeon has released a string of statements supporting the rights of EU nationals to live and work in Scotland, promising to fight "inhumane" Westminster tactics holding foreign nationals as "hostages" in Brexit negotiations (Brooks and Severin 2016). On June 24,2016 , the day after the referendum, she spoke at Bute House in Edinburgh:

[ex]Yesterday, Scotland-like London and Northern Ireland-voted overwhelmingly to remain in the EU. ... We voted to safeguard our freedom to travel, live, work and study in other European countries. ... Indeed, I want to take the opportunity this morning to speak directly to citizens of other EU countries living here in Scotland-you remain welcome here, Scotland is your home and your contribution is valued. . . . I am proud of Scotland and how we voted yesterday. We proved that we are a modern, outward looking, open and inclusive country. (BBC News 2016a) 
Her rhetoric supporting residency rights and her attempts to secure a place for Scotland at the negotiating table on the terms of Brexit has been highly praised among diverse Scottish publics, even those who did not support the Scottish Nationalist Party (SNP) in the 2014 independence referendum.

Indeed, in St. Andrews and further afield in Edinburgh (two towns staunchly opposed to both Scottish independence and Brexit), people from across the political spectrum and electoral demographics are reconsidering their stance on Scottish independence. The SNP has openly challenged the UK government position that people can be placed neatly into "categories and classes that (they happen) to find (themselves) by accident of birth or of later circumstance" (Rapport 2010, 464). Acknowledging how it is becoming more difficult to distinguish between the politics of left and right (Holmes 2000), many people, me included, feel awkward about a nationalist party becoming the progressive voice of cosmopolitanism, freedom, and social liberty, and remain suspicious of shadowy ulterior political motives and the lack of substantial policy in place to support somewhat overblown claims. Sturgeon's words, however, do carry wide appeal and speak for everyday Scots who oppose the political domination (historical and current) of the Conservative English upper classes, which regularly implement cutbacks, provoke crises, and impoverish the rest. Sturgeon has a somewhat cult superhero status. She has managed to build on her previous reputation for 
caring, progressive political futures-in contrast to her steely predecessor, Alex Salmond-to wide appeal and has become a central figure in the imaginative support networks of EU nationals in Scotland. A text from a Greek student studying at another Scottish university read "Power! Nicola Sturgeon kicks ass. She is here to save the day. Watch out dirty Tories." A Greek friend, Katerina, who lives in Scotland, sent me a picture message of Conservative former prime minister David Cameron on the telephone with Greek prime minister Alexis Tsipras asking for advice on how to perform a Uturn and transform a no vote into a yes.

Networks of affective support among migrants in Scotland became even more apparent in October 2016 after the Conservative Party conference, in which UK Home Secretary Amber Rudd announced plans to make universities "more discriminating" in the courses they offer to foreign students and to force businesses to disclose how many foreign workers they employ, leading to accusations that the government's plans had crossed the boundary into "racism" (BBC News 2016b). Further speeches have championed cosmopolitanism in Scottish society, industry, and education, emphasized the important contribution of European nationals to the Scottish economy, and issued reminders about the rich history of multiculturalism and liberty in Scotland since the Enlightenment (Lino e Silva and Wardle 2016). 
Cosmopolitanism is concerned with the plurality of human freedom, with openness and individual expression (Wardle 2010, 386). But the emergent cosmopolitanism in Scotland seems to be fused with a nationalist agenda. For Dennis, like me, cosmopolitanism was part of a long-standing vision for a British nation, something he shared with other Brits, especially fellow Englishmen, or as he put it, "an appreciation of different cultural backgrounds and a duty to welcome any human being who turns up on your doorstep." Cosmopolitanism, Dennis believed, was an existential condition, what might be described as "a moral quality that is embedded in social practices" (Josephides 2010, 394) of being British. Now the waters are murkier, with cosmopolitanism at the center of the nationalist rhetoric for an independent Scotland. But nationalist affirmations of identity ride on the back of landmark events-they are plural and situational, taking countless forms (Rapport 2012b, 68, 70). It is quite possible to express oneself through the trope of metamorphosed nationalism while behaving with civility and upholding the virtues of a social democracy. Cosmopolitanism can emerge through unusual channels, and a significant political event, such as Brexit, provides an alternative route for claims to cosmopolitanism.

The universal yet individual human being "has both the capacity and the right to develop a world-view that fits them personally" (Rapport 2010, 465; see also Rapport 2012a), a right, if unanimously granted and respected, that can be a double-edged sword in the case at hand. In the 
current moment, there seems to be a need to name collectivities, as liberalism is replaced by "cultural communities" that are ascribed fixed identities. This is precisely what Sturgeon does when she constructs the result of the Brexit vote in terms of regions rather than individuals"Scotland, London, Northern Ireland voted to remain"-another form of collectivization that seems to rule out the possibility that the Dundonian Remainer may have more in common with the Mancunian Remainer than with the Dundonian Leaver, an example of how Brexit might help create new forms of relatedness along political lines (Balthazar 2017). For the average Remainer (if there is such a character), ideals of freedom, tolerance, and social liberty are constructed according to a particular kind of cosmopolitanism related to the category of "Europe."

Although categorization is difficult to avoid, many people whom I have spoken to since the Brexit referendum have suggested that the cosmopolitan project should stare down the strategic essentialism from both sides and demonstrate how "a politics of identity based on collective categorizations is deemed neither true nor just" (Rapport 2010,470). Paradoxical though it might seem, some Remain supporters in Scotland might try to undermine essentialism by supporting a nationalist party-in some cases even against their own better judgment-because it claims the universal right to pursue human potentiality across hegemonic categories. 


\section{[h1]The way we were}

[ni]The global economic downturn and years of austerity politics have formed the basis for a succession of divisive election and referendum campaigns. "I could understand if it were Greece that decided to leave Europe," said a colleague who has devoted his life to Hellenic studies. "All that pent-up anger against European bankers and bureaucrats [. . .] in Greece there is a real reason to want to get out of Europe, away from all their meddling and tutelage that has had such an impact on the quality of life for the everyday person." The observable effect of EU membership in the life of the everyday Brit, my colleague suggested, is for the most part negligible.

Further, much of the anxiety of Remain supporters and EU nationals is based on the potential negative implications of Brexit Britain, their speculation about uncertain futures. Brexit has stirred up numerous adverse potentialities while Greeks are already living the consequences of crisis. Yet, although Greece has been brought to its knees by seven years of wage cuts, job losses, and new taxes, support there for the European project remains strong. Despite continued discontent with tactics employed by their creditors, my research participants often expressed a stout sense of European belonging based on notions of Europe as the home of social progress, modernity, liberty, and civilization-what one is inclined to cautiously term "cosmopolitanism" (Knight 2017). 
Perhaps my colleague is out of touch with the "everyday Brit." He, like me, is an Englishman who certainly understands more about his chosen site of ethnographic study than the politics of the country where he was born and raised. Many academics seem to have been surprised by both the Brexit referendum and the US election results, possibly highlighting just how estranged we are from the grassroots reality of the places we call home. Furthermore, we may feel that it is difficult for us to do justice to the moment in any meaningful way.

In the months since the Brexit vote, two recurrent themes have punctuated discourse from the side of Remain supporters and EU citizens living in Scotland-the sense of being trapped in the temporal moment and confusion about futures of cosmopolitanism that seem linked to a Scottish nationalist agenda. Fears over suspended cosmopolitan futures are but one aspect of intense temporal vertigo, the disorientation felt by a particular section of the population. As Sarah Green (2016) has argued, the postreferendum times we are living in constitute a "new normal" of uncertainty, but with renewed political accountability. While for some residents of the United Kingdom the new normal of uncertainty has a very old and familiar feel, for people like Dennis, Giovanna, Katerina, and me, the new normal does not feel normal at all. 


\section{[h1]Notes}

Acknowledgments. For innumerable engaging conversations on Brexit Scotland, I am particularly grateful to my colleagues Sabine Hyland, Stavroula Pipyrou, Nigel Rapport, and Huon Wardle and, away from St. Andrews, Debbora Battaglia, Rebecca Bryant, Gillian Evans and Carol Greenhouse. The three anonymous reviewers provided extensive feedback worthy of a full-length research article, comments which I have fallen well short of doing justice. I thank the Forum editors for the generous invitation and Pablo Morales for his insights and patience in the copyediting process.

1. All names of interlocutors are pseudonyms.

2. "Cool Britannia" was experienced in different ways among the youth of the time and not always with the optimism I witnessed. As always in the United Kingdom, regional, class, and generational differences play significant roles in how the late 1990 s are remembered.

\section{[h1]References}


Balthazar, Ana Carolina. 2017. "Made in Britain: Brexit, Teacups, and the Materiality of the Nation." American Ethnologist 44 (2): TK.

BBC News. 2016a. "Brexit Vote: Nicola Sturgeon Statement in Full." BBC News website, June 24. Accessed December 15, 2016. http://www.bbc.co.uk/news/uk-scotland-36620375.

---. 2016b. "New Immigration Curbs Needed 'to Change Tide of Opinion."' BBC News website, October 4. Accessed December 15, 2016. http://www.bbc.co.uk/news/uk-politics-37549800.

Brooks, Libby and Carrell, Severin. 2016. "Nicola Sturgeon Acts to Reassure EU Nationals Living in Scotland." Guardian (London), July 5. Accessed December 15, 2016. https://www.theguardian.com/politics/2016/jul/05/nicola-sturgeonacts-to-reassure-eu-nationals-scotland.

Bryant, Rebecca. 2014. "History's Remainders: On Time and Objects after Conflict in Cyprus." American Ethnologist 41 (4): 681-97.

- - . 2016. "On Critical Times: Return, Repetition, and the Uncanny Present." History And Anthropology 27 (1): 19-31. de Martino, Ernesto. 2012. "Crisis of Presence and Religious Reintegration." Translated by Tobia Farnetti and Charles Stewart. Hau 2 (2): 431-50. Accessed December 15, 2016. http://www.haujournal.org/index.php/hau/article/view/hau2.2.024. First published 1956. 
Green, Sarah. 2016. "The World after Brexit: Britain's Vote to Leave the EU Has Ushered in a Surprise: It Turns Out That Voting Matters, and the UK Is Living in a New Normal Now." Anthropology News, October 17. Accessed December 15, 2016. http://www.anthropologynews.org/index.php/2016/10/17/the-world-after-brexit/.

Gusterson, Hugh. 2017. "From Brexit to Trump: Anthropology and the Rise of Nationalist Populism." American Ethnologist 44 (2): TK.

Holmes, Douglas. 2000. Integral Europe: Fast-Capitalism, Multiculturalism, Neofascism. Princeton, NJ: Princeton University Press.

Josephides, Lisette. 2010. "Cosmopolitanism as the Existential Condition of Humanity." Social Anthropology 18 (4): 389-95.

Knight, Daniel M. 2015. History, Time, and Economic Crisis in Central Greece. New York: Palgrave Macmillan.

---. 2016. "Temporal Vertigo and Time Vortices on Greece's Central Plain." Cambridge Journal of Anthropology 34 (1): 32-44.

-- . 2017. "Energy Talk, Temporality, and Belonging in Austerity Greece." Anthropological Quarterly 90 (1): 159-84.

- - ., and Charles Stewart. 2016. "Ethnographies of Austerity: Temporality, Crisis and Affect in Southern Europe." History and Anthropology 27 (1): 1-18.

Koch, Insa. 2017. "What's in a Vote? Brexit beyond Culture Wars." American Ethnologist 44 (2): TK. 
Lino e Silva, Moises, and Huon Wardle, eds. 2016. Freedom in Practice:

Governance, Autonomy and Liberty in the Everyday. London:

Routledge.

Rapport, Nigel. 2010. "Cosmopolitanism and Liberty." Social Anthropology 18 (4): 464-70.

---. 2012a. Anyone: The Cosmopolitan Subject of Anthropology. Oxford: Berghahn.

---. 2012b. "Tensile Nationality: National Identity as an Everyday Way of Being in a Scottish Hospital." Anthropology in Action 19 (1): 60-73.

Sykes, Karen. 2016. "The Estranged Citizens of Brexit." Focaal Blog, August 8. Accessed December 15, 2016. http://www.focaalblog.com/2016/08/08/karen-sykes-the-estrangedcitizens-of-brexit/.

Wardle, Huon. 2010. "A Cosmopolitan Anthropology?" Social Anthropology $18(4): 381-88$.

Weszkalnys, Gisa. 2015. "Geology, Potentiality, Speculation: On the Indeterminacy of 'First Oil.'" Cultural Anthropology 30 (4): 611-39. 
Daniel M. Knight

Department of Social Anthropology

University of St. Andrews

71 North Street

St. Andrews, Fife, KY16 6AL

United Kingdom

dmk3@st-andrews.ac.uk 